Article

\title{
Covid-19: A Different Economic Crisis but the Same Paradigm of Democratic Deficit in the EU
}

\author{
Dina Sebastião ${ }^{1,2}$ \\ ${ }^{1}$ CEIS20-Centre of Interdisciplinary Studies, 3000-186 Coimbra, Portugal; E-Mail: dinasebastiao@gmail.com \\ 2 Faculty of Arts and Humanities, University of Coimbra, 3004-531 Coimbra, Portugal
}

Submitted: 14 December 2020 | Accepted: 10 February 2021 | Published: 27 May 2021

\begin{abstract}
Based on a normative orientation and an interdisciplinary perspective, this is a comparative study, using the process tracing methodology, between the EU responses to Eurozone and Covid-19 crises to assess if, despite different outcomes, institutional decision-making processes evidence a change. The study concluded that the EU democratic deficit remains, which assumes special features in economic crises, providing a political oversize power to the economically hegemonic states, thus constraining ideological debate and making national interest prevail over politicisation. This perpetuates the conversion of structural economic positions into political power at the expense of political representative power and democracy.
\end{abstract}

\section{Keywords}

democratic deficit; Covid-19; EMU governance; Eurozone crisis

\section{Issue}

This article is part of the issue "Reforming the Institutions of Eurozone Governance" edited by Anna-Lena Högenauer (University of Luxembourg), David Howarth (University of Luxembourg) and Moritz Rehm (University of Luxembourg).

(C) 2021 by the author; licensee Cogitatio (Lisbon, Portugal). This article is licensed under a Creative Commons Attribution 4.0 International License (CC BY).

\section{Introduction}

Eurozone debt and Covid-19 economic crises can be considered as 'critical junctures' (Braun, 2015, pp. 421-422; Heinrich \& Kutter, 2013, pp. 124-126; Ladi \& Tsarouhas, 2020, pp. 1042, 1051-1052; Schmidt, 2020, pp. 1179, 1182), understood as a sequence of abnormal and unexpected events, exogenous to the political system, requiring reactions and answers that may result in institutional change, impacting political institutions and policies (Capoccia, 2015; Stark, 2018). Therefore, they are also opportune moments for assessing the democratic legitimacy of the EU.

Based on a comparative analysis of the EU responses to both crises, this research assesses the importance of the constitutional design to allow politically balanced outcomes and prevent economically biased decisions. The study departs from the hypothesis that the existing institutional design leads to an oversized political power of a few economically hegemonic states, tending to achieve inexpedient outcomes and to reproduce struc- tural economic imbalances. The research is normativeoriented, relying on the importance of the constitutional architecture of the EU in the context of economic crises to grant democratic legitimisation.

The first part of the article presents the methodological approach that is used, the second provides a theoretical review of the democratic deficit in the EU, while the third part presents a short description of responses to crises; finally, the fourth section delivers the empirical analysis supporting the hypothesis and anticipating lines for discussion and conclusions.

\section{Methodology and Empirical Analysis}

Process tracing (PT) methodology is used for empirical qualitative analysis of the institutional reforms and policy outcomes following the Eurozone and Covid-19 crises. PT is a causal inference methodology based on a diagnosis of causal activities and/or events to build rational arguments for hypothesised explanations of a certain phenomenon (Bennett, 2010, p. 208). An accurate 
qualitative analysis to observe causal mechanisms is made (Beach \& Pederson, 2016, p. 163; Collier, 2011, pp. 823-824), through a detailed and sequenced method for rational inference, grounded in tracing previous events of a result to argue its causes and provide theoretical hypotheses to the outcomes' causality. It may be a means to both testing and building theories, or to merely explaining an outcome (Beach \& Pederson, 2016, p. 2). This research uses theory-testing approach to PT to find evidence that the already theorised democratic deficit is the cause of the hypothesis posed, intending to demonstrate that despite evidences of policy change in Covid-19 crisis, the same democratic perversion happened in institutional mechanisms.

Theory-testing-driven PT takes theory from literature to demonstrate that it is present in the form of causal mechanisms-events/activities observed and subject to inference-fostering a certain outcome. It is viable when a grounded theory already exists from which a plausible mechanism may be deduced and forward-tested in a case study (Beach \& Pederson, 2016, pp. 12-15, 29, 164). The further identified causal mechanisms are defined as derivations of the democratic deficit underpinning the rationale of this research. Therefore, $X$ and $Y$ must be present in the PT inference, where $X$ is hypothesised to lead to $Y$ (Bennett, 2010, p. 209). In this research, $X$ is defined as the democratic deficit and $Y$ as the oversized political power of the economically hegemonic states. To prove the correlation, events/activities are described, reasoned and conceptualised as manifestations of $\mathrm{X}$, that is, of the theory on which the analysis is based (Collier, 2011, pp. 824, 825). Primary and secondary sources are used, such as institutional EU documents, political testimonies, news media, and scientific literature, covering the 2009-2015 period, the peak of the Eurozone debt crisis, and the period between February and September 2020, related to the analysis during the pandemic. The PT approach is rooted on a normative orientation, derived from the democratic deficit theorisation of the EU political system, and specifically the EMU institutional architecture.

\section{On the Democratic Deficit of the EU and EMU}

The EU and the EMU have long been diagnosed by scholars as suffering from democratic deficit and legitimacy. Although these two terminologies may overlap when assessing democracy in the EU, they have differences when considering the criteria and scope of assessment of a political system. While the democratic deficit is based on the principle of a constitutional design corresponding to representative democracy for legitimising the exercise of power, legitimacy, although it may entail premises of democratic procedures, aims at assessing the degree and breadth of recognition by the people of the exercise of authority. For legitimacy to be achieved, people should not only recognise that a government exercises the power, but also that it has the right to have that authority. Even though a democratic based constitution is an important criterion for that recognition, other factors are important, as the governmental outputs, the habit to it, and historical and identity issues (Shively, 2011, pp. 185-188). So, a political system can be democratic deficient but enjoy legitimacy by its people, and the other way around. Whereas the democratic deficit debate deals with the need for democracy to procedurally legitimise the EU's authority, the legitimacy deficit studies deal with the substantive approval of EU governance (de Jongh \& Theuns, 2017).

Such assumption helps to understand why in the first decades of integration, outputs appeared to be sufficient to legitimise the EU (Habermas, 2013, p. 2), while lasting peace and economic growth sided by the welfare state pleased the electorate (Sebastião, 2020, p. 139). This permissive consensus (Inglehart, 1970) was propitious for questioning democracy as being inadequate to conceptualise the EU, as it could be alternatively conceived as a regulatory state (Majone, 1996), where the Pareto principle operated. This meets the conceptualisation of results as pertinent criteria to observe legitimacy, as advocated by Scharpf (1999), backed by the systemic approach to political systems: Despite the effective outputs for citizens, the citizens' participation in the governing process, through parties and elections-the inputs-were also important (de Jongh \& Theuns, 2017, p. 1286; Scharpf, 1999; Schmidt, 2013, pp. 4-5). Outputs stood out as legitimisers in literature (Caporaso \& Tarrow, 2008; see also Menon and Weatherill, as cited in Schmidt, 2013 , p. 11), but systemic-based studies even developed throughput as a third criteria (Schmidt, 2013, p. 7), coincident with the institutional procedures of the EU, that should ensure effectiveness, accountability, transparency, inclusion and openness to civil society (Schmidt, 2013, pp. 15-19).

Nevertheless, outputs have been controversial as legitimisers, and the 2008 crisis reinforced this notion, leading some authors to review those presumptions (Scharpf, 2010). For Follesdal and Hix (2006, pp. 543-545), the central question is how to define effective outputs. This is a matter of politics and democracy, requiring competition and opposition, not only to elect the best policy but even more important for choosing an alternative government when policy outcomes have disappointed citizens. When outputs are not satisfactory, what is questioned is not the legitimacy, but rather the effectiveness of a government. However, it is indeed these moments that demonstrate a permanent dialectics between legitimacy and people's expectations regarding the democratic procedures (de Jongh \& Theuns, 2017, pp. 1288-1292). Political competition and majority-based institutions are even more crucial when outcomes have not lived up to citizens' expectations and an alternative is needed. In fact, despite the political empowerment of the European Parliament $(E P)$, it has not been proportional to the range of competences transferred from national parliaments to the 
EU. Intergovernmentalism weighs too heavily on the balance of powers (Schmidt, 2007, p. 521), and this has remained unchanged even with Spitzenkandidat (Moury, 2016, pp. 38-48), making the EU a kind of "imperfect bicameralism" (Moreira, 2017, p. 55).

These claims depart from the premises of representative democracy, underpinning the EU democratic deficit arguments, assumed as the theoretical rationale of this research. Free and competitive elections are the pillar of representative democracy, electing officers, that are mediators of social conflicts, representing the electorate, and holding legislative and executive power. Most representative democracies are parliamentary systems, where government emerges from the party leader, or coalition, winning a majority of votes in parliament through the general election. Parliament and government exert legislative and executive power respectively, with a close interdependent relation. Another model of representative democracy is the presidential one. A president is elected by universal suffrage, assuming both the executive and head of state roles, with great independence from the parliament, that holds legislative power. There's still semi-presidential and semiparliamentary models, which share characteristics of the former two, with more or less executive or control power by the president vis-à-vis the government (Delwit, 2015, pp. 146-155; Fernandes, 2010, pp. 148-158).

Based on representative democracy premises, this research shares Hix and Hoyland's (2011, p. 131) judgment, that a truly democratic EU would require elections to be the provenience of the main political offices (as the President of the Commission) and the control of the political agenda. Political competition in EP elections would provide voters with policy platforms or candidates for office and allow alternative choices when a mandate defrauded citizens' expectations. The authors have five main arguments for democratic deficit in the EU: (1) The EU decisions are too dependent on executive actors, as the governmental ones, (2) EP power remains too weak, once its empowerment was not proportional to the loss of national parliaments' power, (3) there is an absence of truly European elections, given the 'domestic' logic of EP elections, (4) there remains a distance of the EU from its citizens, considering the complex institutional design and the secrecy features of some institutions and (5) EU policies are not a translation of the majority of European citizens' preferences (Hix \& Hoyland, 2011, pp. 132-133).

These claims are flagrant in the EMU architectural design, particularly within the economic governance. Furthermore, when considering the dialects between EMU norm and political economy, democracy is subject to particular perversion.

\subsection{EMU and Democracy Constraints in a Multilevel Polity}

Institutionalised in the Treaty of Maastricht, under the German ordoliberal model (Habermas, 2013, p. 3; Lang,
2004), the EMU operationalises the monetarist ideology (Bellamy \& Weale, 2015, p. 259) through two different forms of governance: a 'federal' one, governing monetary policy under the European Central Bank (ECB) political independent authority, and a national coordination for economic policy. This accommodated a supranational monetary policy, but the denial of EU co-responsibility for Eurozone fiscal balances, designing the EMU as a non-optimum currency area. Whereas monetary policy is supranational, under the ECB political independence to maintain price stability (Chang, 2009, p. 68), the economic policy is a national competence, but subject to very strict coordination, preventive, surveillance, and punitive mechanisms by the EU, ensured by a reinforced intergovernmentalism, through the open method of coordination. The Stability and Growth Pact (SGP) is the central instrument of this economic governance, setting limits for national public debts and deficits, as well as margins for inflation and interest rates, to ensure prices stability, credit markets confidence, and thus the soundness of the single currency, on the benefit of all the Eurozone members (Chang, 2009, pp. 124-125; Silva, 2017, pp. 69-73). So, while the EMU deprived national governments of a traditional macroeconomic instrument, as the monetary policy, important to face crisis and asymmetric shocks, the EU did not assume a correspondent competence with supranational instruments to ensure it, leaving it under exclusive national responsibility. Furthermore, given the great economic structural differences between the Member States, a single currency and a macroeconomic policy on the type of one size fits all, was likely to replicate national imbalances and generate economic irrationalities-as the competitive and unfair national fiscal policies with dichotomous effects across Member States (Lang, 2004, pp. 151-157; Ruchet, 1998, pp. 168-177). As fiscal instruments rested to be one of the few national automatic stabilizers, each state would adopt the ones that its structural economic position in EMU is in advantage for, thus engaging in national fiscal competition.

Although this multi-level governance is underpinned by legal constitutional principles conferring normative legitimacy to the EMU (Bellamy \& Weale, 2015, p. 259), when considering implications for the normal process of democratic politics, the imposed restrictions to public finances limit ideological competition over political economy, the reason Bellamy and Weale (2015, p. 259) assume EMU represents a kind of neoliberal institutionalization. This is what the German constitutionalist Dieter Grimm (cited in Habermas, 2015, p. 547) identifies as the "constitutional status" of some EU policies, which turn them immune to the normal process of variation in politics, one of the causes for the distance of the EU from the citizens. Such a conditioned EMU tightens the ideological options between the traditional proliberal and pro-Keynesian stances of the political economy of European democracies, thus depoliticizing economic options (Parker \& Tsarouhas, 2018, pp. 11-12). 
This is very clear when considering the clash of formal national and supranational norms in economic governance: If the national parliaments are the ultimate sovereigns on budgetary policy, they are simultaneously limited on political options by the EMU financial criteria. The democratic legitimacy is also weakened by the fact that the EP has neither formal competencies in coordinating and supervising SGP mechanisms nor in the monetary policy. The ECB institutional independence from any political EU organ, not only undermines accountability of the monetary policy, as well as remits a highly influential policy in national politics to a technocratised scope of action (Snell, 2016). And the responses to the Euro crisis have strengthened ECB role without modifying accountability processes (Heidebrecht, 2021).

The Eurozone crisis unveiled those institutional dysfunctions, making quite evident the structural inadequacy of the EMU to address international economic downturns, as well as the high systemic risk of the unregulated European banking. Moreover, it was also clear that its political economy consolidated two different and antagonist, but interdependent, models of economic development in the EU-exporting competitive economies/creditor States versus weak and low competitive economies/debtor States (Parker \& Tsarouhas, 2018, pp. 5-6; Reis, 2016, pp. 46-48). While the former accumulated liquidity and needed to capitalise it, the latter needed credit for public investment and to boost the economy. Although antagonism could coexist in economic growth scenarios, it proved unsustainable with the crisis (Sánchez-Cuenca, 2017, p. 357).

\section{Addressing the Eurozone and Covid-19 Crises}

Empirical analysis consists of two parts: a summary of the measures to tackle the crises and the other the argument of the hypothesis. The EU has addressed the Eurozone crisis with emergency financial measures and legal reforms to correct the EMU governance structure. Backed by loans from the IMF and the EU, the first consisted of bailout programmes approved for Greece, Ireland, Portugal, Spain and Cyprus, under conditions for correcting macroeconomic imbalances (Parker \& Tsarouhas, 2018 , p. 2). Required to be achieved in the short term, it involved a deflationary policy without compensation for securing levels of demand-except for the ECB purchase programme (ECB, 2012), aggravating economic recession and social exclusion to the extent that IMF later recognised the exaggeration of the deflationary policy (Elliot, Inman, \& Smith, 2013).

Concerning legal reforms, the six-pack (2011) and two-pack (2013) programmes reinforced the financial criteria with stricter rules for national budgetary policy and new governance procedures to operationalise strengthened coordination and surveillance. The Fiscal Compact (Gouveia, 2018, p. 123) completed this package by requiring a binding national law to make the strengthened SGP provisions effective (art. no. 3(2), TSCG). To address the problem of systemic risk in Eurozone banks, a banking union was launched, still unfinished, ensuring single supervisory and resolution mechanisms (Pereira \& Sousa, 2018, pp. 81-96).

Regarding the Covid-19 crisis, the first measure was the adoption of the general escape clause which provided for full flexibility available in the SGP in severe downturns (Council Regulation of 8 November 2011, 2011; European Commission, 2020b; European Council, 2020a; European Parliament Regulation of 16 November 2011, 2011). Additionally, financial funds were made available: a first loan of $€ 200$ billion for businesses through the European Investment Bank (2020), and a second temporary loan-based instrument of up to $€ 240$ billion by the Eurogroup, through the ESM (Eurogroup, 2020). In March, the ECB announced a $€ 750$ billion Pandemic Emergency Purchase Programme (ECB, 2020a), reinforced in June by $€ 600$ billion as a result of falling inflation (ECB, 2020b).

The ground-breaking EU response was the approval by the European Council in July of the European Commission's "Next Generation EU" proposal, a $€ 750$ billion recovery plan (European Council, 2020b) divided into grants and loans to be made operational through various financial instruments (European Commission, 2020a), framed as an addition to the $€ 1,074$ trillion Multiannual Financial Framework (MFF). Although the European Council's approval was only possible after a revision reducing the initial amount proposed for grants from $€ 500$ to $€ 350$ billion (Boffey \& Rankin, 2020; Rankin, 2020), this may be an historical agreement to boost integration, making it a step forward to creating European public debt and fiscal competences (European Commission, 2020a; European Council, 2020b).

\section{Hypothesising: Political Oversizing of Economically Hegemonic States}

Departing from a PT theory-testing approach, argumentation to the hypothesis is structured along a diagnosis of causal inferences based on three derivations of the democratic deficit: (1) junctural constraints, (2) institutional constraints and (3) constitutional constraints (Figure 1). The first one relates to the influence of critical economic junctures on the increase of political over-power of the richest States, mainly through the financial markets pressure that activate economic pathdependency in the EU; the second one relates to the secrecy of bargaining and discussions, strengthening the political power of stronger economies and depoliticisation. Finally, the third one builds on the status of a deEuropean Commission.

\subsection{Junctural Constraints}

This causal event acts as a political power booster of the most powerful economic states in economic crisis, towards the urgency of weaker economies to choose 


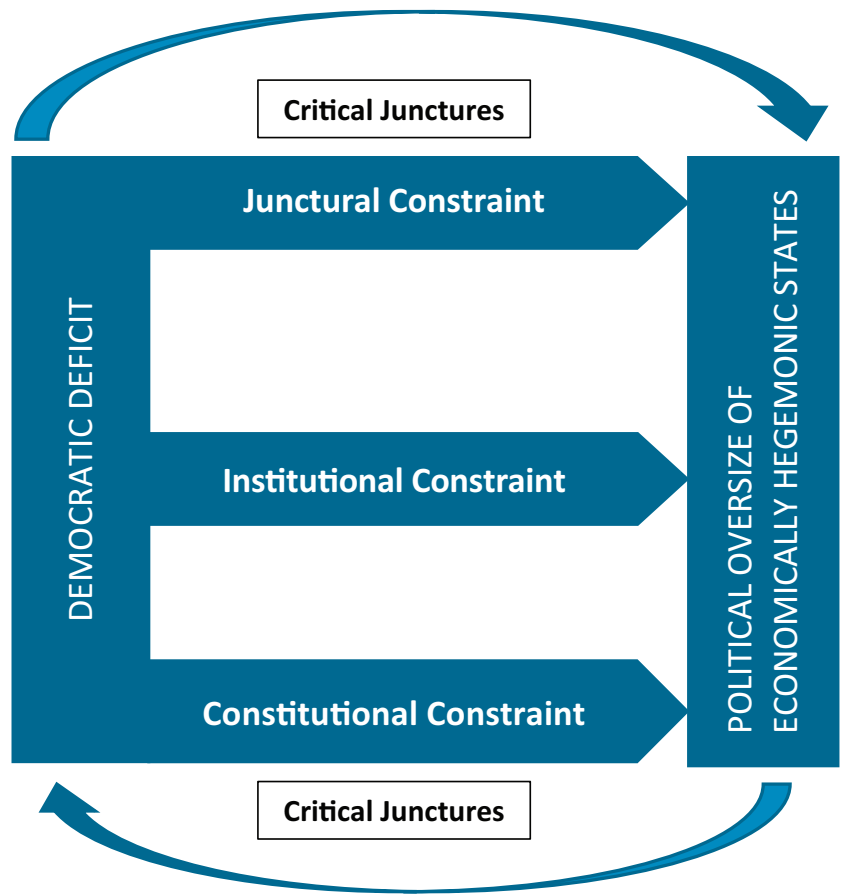

Figure 1. Causal inference supporting the hypothesis: repercussion of democratic deficit into the political power of hegemonic economies happens through junctural constraints (related with the economic and financial crisis features), institutional constraints and constitutional constraints.

the least bad policy (see Figure 2). This relies upon the assumption that Eurozone and Covid-19 crises are critical junctures. Unleashed by the external shock of the 2008 global crisis, the Eurozone debt crisis placed the EMU's historical path-dependencies under instability and threat, posing the need for decisions on emergency financial measures and new institutional arrangements in three policy areas (Braun, 2015, pp. 421-422). As a moment of great uncertainty, avenues for fundamental revision are opened, which can leverage a rupture or just a transitional period, that may not culminate in a de facto change (Heinrich \& Kutter, 2013, pp. 123-125).

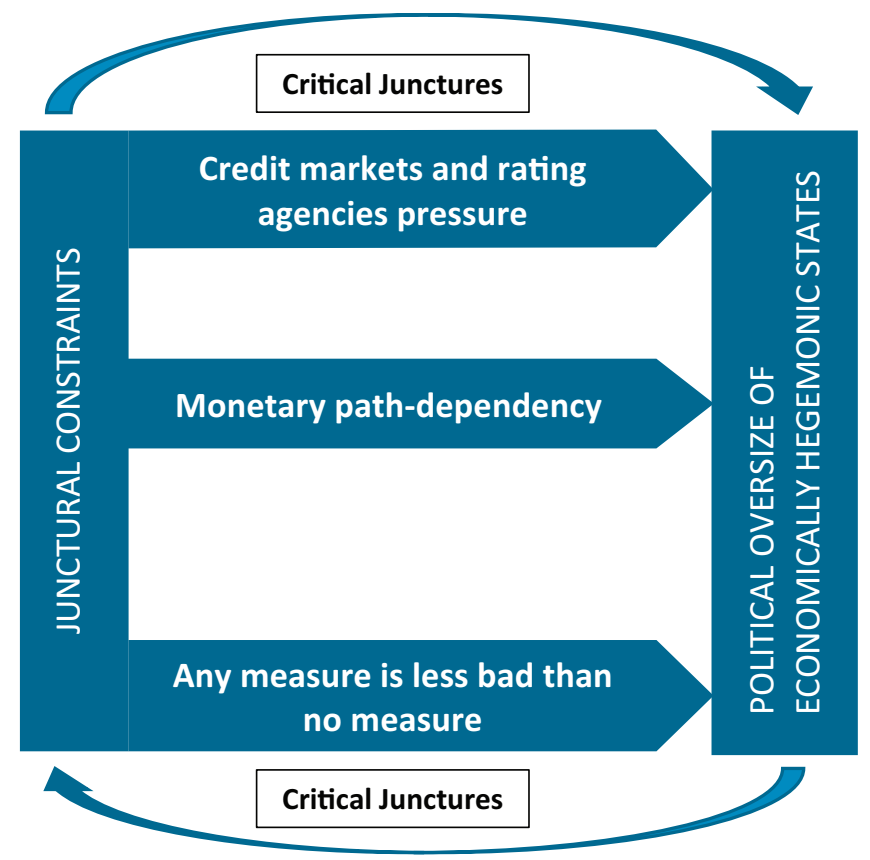

Figure 2. Causal inference of the 1st constraint: Junctural constraints act with financial market pressures or effects of severe economic downturns, external to the EU, but activating other two causal mechanisms internal to EU, with economic and monetary path-dependency and the result of this, the exclusion of a no measure scenario. 
The Covid-19 pandemic reached the EU also as an external shock, first in the form of a health crisis, that spilled over to an economic crisis. As long as the economic consequences turned clear, with a symmetric (and not asymmetric, like in 2008) expected impact, Member States perceived they were facing an existential hazard to the single market and the EU itself (Lady \& Tsarahouas, 2020, pp. 1041-1043). Both crises required extraordinary responses, but whereas in the former it is generally assumed, despite arguments that ECB made an ideological change (Braun, 2015, pp. 431-436), that there was not a policy paradigm shift-rather an incremental change through the persistence of policies and historical institutional mechanisms (Heinrich \& Kutter, 2013; Verdun, 2015)-during the Covid-19 pandemic there appeared to be a learning process that led to substantial policy change (Lady \& Tsarahouas, 2020, pp. 144-151).

But if this historical institutionalist approach to critical junctures explains policy change or permanence, it is not sufficient to clarify if the implied institutional trajectories altered (Schmidt, 2020, p. 1181). By relating junctural constraints with answers to both crises, in a comparative perspective, it is intended to demonstrate that the supposed learning process by some political agents in Covid-19 does not suggest evolution on institutional mechanisms, and thus not in the inherent democratic deficit.

Despite the evidence of path-dependency (Capoccia, 2015; Stark, 2018) on economic damage during the Eurozone debt crisis, the financial urgency had the potential for greater losses for weaker economies. The legal and political answers provided did not change the EMU ordoliberal political economy paradigm (Hillebrand, 2015), with deficit economies carrying the burden of a rapid financial adjustment (Hillebrand, 2015, pp. 16-17). While it's true that those States reported historical financial imbalances, the crisis also showed that the economic EMU path-dependency was sustained in two dichotomic models of growth, underpinning a 'federal' currency with which they all capitalise their economic structural position.

The interest of the creditor economies in facilitating credit to the deficit ones expressed that pathdependency, since guaranteeing liquidity to the latter could systematically guarantee liquidity to the banking creditors of the former (Copelovitch, Frieden, \& Walter, 2016 , p. 828). An alternative argument is that threatened Member States could veto solutions. This is true. But 'junctural constraints' as a causal event answer this. If the Troika memoranda were not accepted and a Member State would leave Eurozone, national economic losses would be higher than the austerity imposed, given the pressure from the credit markets and rating agencies. If in theory they could use the veto, in practice the EMU path-dependency of this crisis, considering the more fragile position of weaker economies, gave no alternative.

Greece is an example thereof. Despite government attempts to renegotiate the memorandum to reduce social consequences and cyclical economic impacts, the alternative bailout plan presented by the finance minister, considered credible by some counterparts, was rejected by the Eurogroup and the European Council (Varoufakis, 2017, pp. 389-422). Even the national referendum that denied the memorandum terms had no impact on intergovernmental bargaining. In view of the worsening of the financial situation, to the extent that the national cash withdrawals and ECB banking liquidity guarantees would be limited, Greece had no choice but to accept severe national solutions (Varoufakis, 2017, pp. 423-431). Even considering the historical selfresponsibility of Greek debt and budget deficit (Gkasis, 2018, pp. 95-102), macroeconomic interdependency is a fact in the single currency, and bankruptcy or exit from the Eurozone would not only have dramatic economic effects for Athens, but also a significant impact on surplus economies, like Germany (Moury, 2016, p. 74).

The same political hegemonic influence of the strongest economies applies to Covid-19. Faced with the pressure on health services and the economy, governments had no choice but to increase public spending, leading to general national budget deficits (Arnold \& Fleming, 2020; European Commission, 2020c), a background for resorting to the escape clause in the SGP. Although this clause was only introduced in the six-pack amendment following the 2008 crisis, in practice the same solution could have been achieved in the debt crisis. As the European Council is the decision-making body on the correction procedures of deficits, it could have adopted, protected by the SGP regulations which do not define correction periods (Council Regulation of 7 July 1997, 1997a, 1997b), longer time frames for budgetary adjustments, relieving social and economic damage to debtor states.

Furthermore, the different nature of this crisis has made richer economies opt for different solutions. While in the Eurozone the financial systemic risk could be solved with measures directed to debtor countries, when it comes to Covid-19 the situation is different. It has affected all Member States alike, although some do have stronger structures to recover from it (Khan \& Arnold, 2020). Secondly, reaching the world market, it has high potential to affect exporting economies in the EU27 (European Commission, 2020d, 2020e). Thirdly, a repetition of the Eurozone austerity could seriously question the benefits of being in the Euro, making it politically unsustainable, because the damages of exiting could be lower than those of a new austerity ("The Eurozone nine," 2020; "The new channel of Eurozone instability," 2020). The perception that the single market was under a symmetric shock, posing a serious existential threat to the EU, led politicians to engage in different institutional answers (Ladi \& Tsarouhas, 2020, pp. 1046, 1047).

It is therefore in Germany's interest to support the joint debt. From the moment 'Coronabonds' was on the Eurogroup agenda, while the prominent 'frugal four' (Netherlands, Austria, Denmark and Sweden) 
were decisively against it, Germany opted for a discrete stance as the pandemic was evolving and consequences were not quite clear. Later in May, Angela Merkel undertook with France to support the European Commission's recovery plan of $€ 500$ billion in grants (Boffey, 2020), and the 'frugal four' accepted it in July (European Council, 2020b).

Path-dependency was thus a driver for the Covid-19 outcomes, but path-dependency was also observed in the Eurozone crisis and, despite emergency financial measures taken, the issue of joint debt as medium/longterm solution for EMU governance was revealed by EU institutions (European Commission, 2011a, 2011b, 2012; European Parliament Resolution of 15 February 2012, 2012) but was not followed up. Germany's support was the element of change in Covid-19, dragging the 'frugal four.' Nevertheless, even the approved solution was not an optimal one, which leads to the second causal event.

\subsection{Institutional Constraints}

This causal event is based on two institutional decisionmaking characteristics: unanimous voting, capitalising economic into political 'representative' power, and the secrecy of intergovernmental bargaining, making national interest a driver of debate to the detriment of ideology (see Figure 3).

Unanimous voting makes decision dependent on one or a few Member States, equivalent to a minority of the population. While in the Eurozone crisis this was not a blatant issue, as a group of northern countries around Germany rejected expansionary policies against southern Member States with France (Schoeller, 2019, pp. 131, 132), this situation is clear in the Covid-19. The unanimity rule empowered few Member States (the 'frugal four') to influence the reach of outcomes (Zalan, 2020), with consensus reached only with a significant reduction of the initial proposal and concessions relating budgetary contributions. Obviously, in parliamentary and open debates, negotiation must also occur. The point here is that unanimity oversized the will of few political actors, representing a minority of the population. Even changing their extreme initial position to support the EU public debt, the four States with low population density but strong economies were able to influence the Commission's proposal for a suboptimal achievement in a way that could not otherwise be possible if there had been a majority voting. An alternative institutional argument is that the veto can be exercised by both richer and poorer states to reject a suboptimal outcome. But economic junctural constraints undermine its feasibility, as argued in the previous causal event. For weaker economies, the least bad outcome is preferable to no solution at all.

The second causal event relating to the secrecy and informality of the intergovernmental bargaining is argued to limit or even prevent ideological debate in favour of nationalist arguments, thereby restricting alternative policies and legitimising the institutionalised economic policy through the official press releases and statements following the Eurogroup and European Council meetings. An example is the failed attempt of the Greek Minister of Finance in 2015 to formally present and discuss in the Eurogroup an alternative plan to the Troika memorandum, which was blocked by the Eurogroup president. Given the absence of formal rules

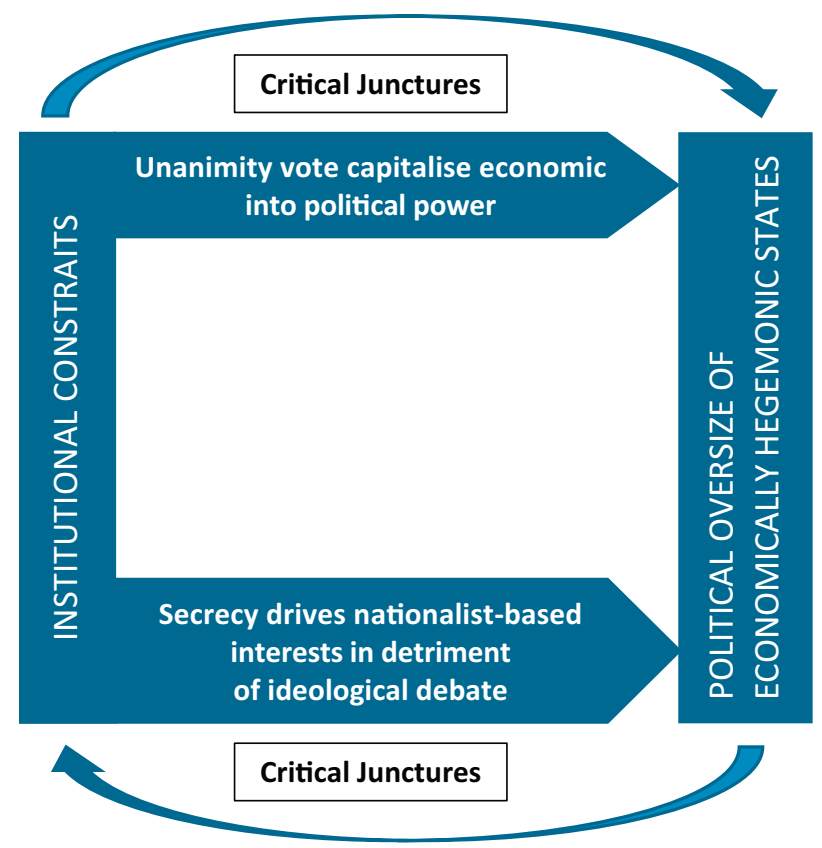

Figure 3. Causal inference for the 2 nd constraint: Institutional constraints act with causal effects that may be common to other policy areas, with unanimity vote and secrecy effects on the political transparency and equity of decision-making, which in economic governance translates economic power into political power. 
for Eurogroup meetings (Abels, 2018), he was unable to oppose the president's blockades (Varoufakis, 2017, pp. 430-431). Ideological debate on the political economy of the EMU was abolished, which could have resulted in some peers perceiving that different economic policies could achieve equal outcomes. Informality and secrecy, as in European Council meetings, limit or even prevent ideological debate, diminishing the ability to persuade public opinion and peers with alternative policies, turning the process more technocratic than political, one of the causes of democratic deficit (Hix \& Hoyland, 2011, p. 132). Political economy, the core of political competition in Western democracies, is reduced to institutionalised technocracy in the Eurozone governance.

This causal event is not a denial of the legitimacy of intergovernmental bodies to defend national interests, or that national interest is not legitimate in a shared sovereignty polity like the EU. The crux of the matter is that when a Member State wants to use ideology to conduct a debate, argue about national interests and envision the EU's future, it is highly constrained by institutional norms. The EP is of course the EU's politicised institution par excellence, and a counterargument is that ideological debate is conducted therein. Nevertheless, in EMU governance, the EP has no formal powers and even in the approval of the Covid-19 recovery plan requiring the EP's decision, it does not have the media impact like the European Council. Moreover, it is as legitimate for governments to use ideological arguments in national competition as it is at the EU level.

This causal event does not presuppose that ideological debate is forbidden or never takes place in the Eurogroup or the European Council. It merely argues that informality and secrecy limits the occurrence and the potential of the political reach of ideological arguments. As Kutter (2020) concludes, despite the discursive politicisation in media and national fora, with alternative narratives about the Eurozone crisis and scenarios for the future of EMU, they did not reach EU policy-making and institutional discourse. Taking into consideration a hypothetical situation in Covid-19, if debate were public there could be arguments explaining that the joint debt does not mean direct transfers of creditor to debtor countries, as the traditional MFF; and that EU fiscal competences could combat tax evasion and regulate the market for the sake of the collective interest. If mediatised, such debate could improve public opinion and counterbalance governmental messages for domestic political competition purposes (Darroch, 2020).

\subsection{Constitutional Constraints}

The last causal event relies in one of Hix and Hoyland's (2011, p. 131) arguments of the democratic deficit, that an unelected President of the Commission is deprived of the power to use the will of citizens to conduct negotiations. As power depends solely or heavily on intergovernmental structures, and as the president of the EU's executive body does not ensue from a direct representative majority and is not subject to an electoral process after the legislature, she/he is unable to politically use citizens' demands to oppose the European Council's power game and strengthen his/her intermediation role in the bargaining (see Figure 4). As he/she is not entitled to be a political intermediary of the EU's constituencies and a promoter of politicisation, they are trapped within

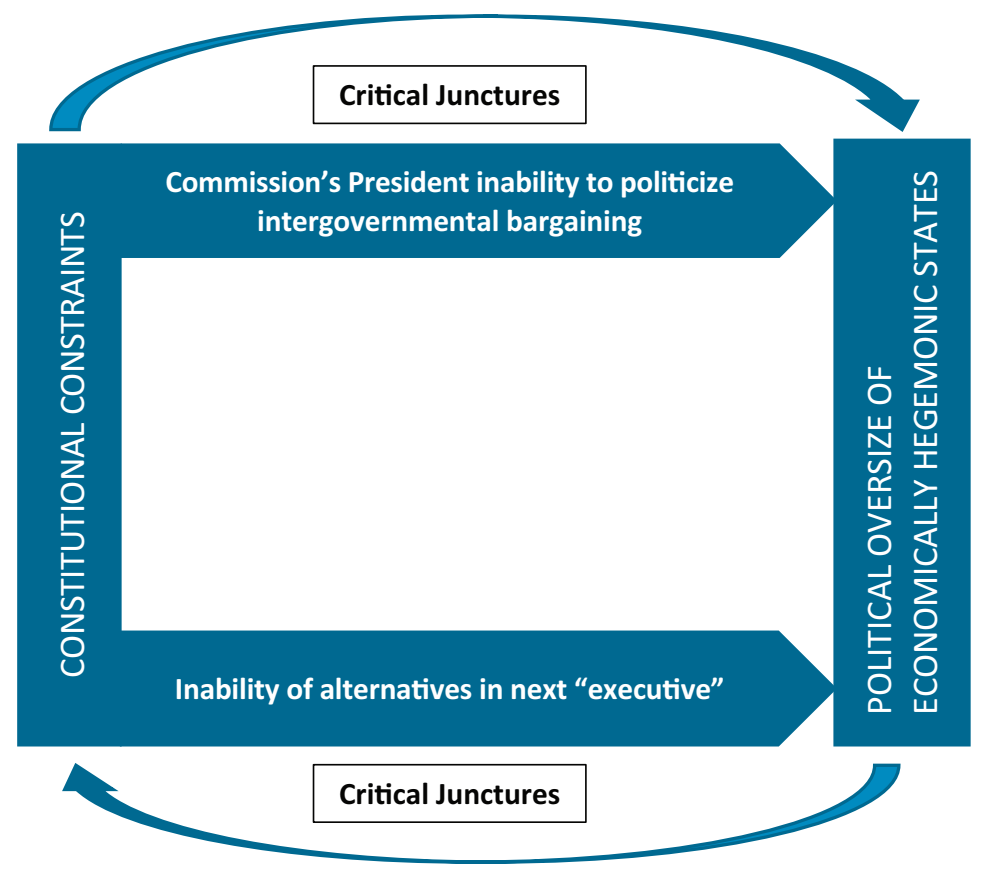

Figure 4. Causal inference of the 3rd constraint: Constitutional constraints derive from the absence of an election-based executive power, which in economic governance perpetuates economic power as the driver of change. 
national interests and efforts are mainly channelled to reaching consensus. This, again, contributes to depoliticised outcomes of the EU economic governance.

It is true that even empowered by a majority voting, Commission could not succeed in approving different outcomes, but representative power could have effects in the medium term, influencing a change for the next legislature. We recall that in the Eurozone crisis, joint debt issuance was called for by the Barroso Commission (European Commission, 2011a, 2011b, 2012) and the European Council Presidency (European Council, 2012) as a structural measure for the Eurozone. While literature points to the Commission's lack of leadership to formalise a proposal (Schoeller, 2019, pp. 132-135), the fact is that it faced a status quo headed by the firm German opposition ("Merkel on eurobonds," 2012; Traynor \& Wintour, 2012), leading it to weigh the costs of going against it (Schoeller, 2019, pp. 135-141). Even the Juncker Commission did not succeed when making a similar proposal (European Commission, 2015), despite the discussion on a common budget for the Eurozone. The Von der Leyen Commission succeeded in 2020, with the EU's constitutional design remaining the same, only with the shift in German's position being different (Boffey, 2020). But while the Covid-19 responses appear to be more equitable for the EU Member States and trigger a policy change in economic governance, this does not remove constitutional constraints. The shift in Covid-19 outcomes were as much allowed by the hegemonic economy as was restrained by the remaining 'frugal four,' managing to refute the Commission's proposal in a way that a majority rule would have found difficult.

The hypothetical power of a majority-based Commission gains ground when considering the EP adoption, in April 2020, of a resolution calling for a massive recovery package based on the reform of the EU's own resources through enhanced fiscal capacity (European Parliament, 2020), or that the EP had already accepted in 2012 eurobonds could be a medium-term solution for stabilising the Eurozone (European Parliament Resolution of 15 February 2012, 2012), exercising leadership on the issue, but restricted by the limits of constitutional design (Schoeller, 2019, pp. 150-157).

Obviously, in the field of a shared sovereignty polity, the citizens' chamber is balanced with the states' representative power; however, recalling the second causal event, the unanimity rule causes disproportionate power in favour of a smaller group of economically hegemonic states, thus undermining the Commission's ability to push for politicised-based results to the detriment of nationalist-based ones. Of course, the opposite would not be a guarantee that the results would always meet the demands of the citizens, but if this was not the case the electorate could have a say in the choice of the next executive, which would appease the issue of democratic legitimacy (Follesdal \& Hix, 2006, p. 548).

\section{Discussion and Conclusion}

Studies of democratic legitimacy about the EU abound. What this interdisciplinary research aims to demonstrate is that the damage of the EU's democratic shortcoming aggravates, by spilling over into the field of economic governance, tending to permanently convert economic power into political 'representative' power, in the result of the structural national positions in institutional path dependencies of EMU, thus reproducing economic and political inequalities. If responses to the Covid-19 crisis suggest that a policy paradigm shift occurred, this does not translate to a change in this state of affairs.

The research confirms the spillover and pathdependency logic of integration, leveraged by the FrancoGerman axis at critical junctures. However, this study adds to the debate the conclusion that democracy has been especially perverted in economic critical junctures, when decisions are either blocked or unblocked by the strongest national economies in their interest, and the EU economic governance is a decisive perpetrator of this. If EMU's institutional mechanisms paved the way for two different models of economic growth with antagonist but interdependent interests, economic critical junctures tended to perpetuate the political over-hegemony of previous surplus economies, when one considers their democratic representativeness. Even admitting that the economic policies achieved can also be in the interests of loss-making economies, the problem is that the constitutional design allows the perpetuation of logic of economic power corresponding to political power, disregarding political representation as such.

Nevertheless, it is admissible that the Covid-19 crisis led to different governmental perceptions and a disruptive answer by the EU agents. Its outputs opened avenues for a change in the political economy of the Eurozone, with prospects of a fiscal union, redistribution, and joint debt at the supranational level, as Ladi and Tsarouhas (2020) conclude. But this was again a decision triggered and conditioned by the hegemonic economies, either the decision of advancing for a different solution or the difficulties posed to restrain the original proposal. The literature explains this as a consequence of the structural indeterminism of critical junctures (Braun, 2015, p. 423), boosting the dominant narratives and empowering (even more) the most powerful actors (Heinrich \& Kutter, 2013, pp. 124-125). It is plausible that the German position was essential to determine the responses to Covid-19 (Ladi \& Tsarouhas, 2020, p. 1052), but such an assumption reinforces our argument on the permanence of institutional mechanisms, allowing the economic hegemonic states to be decisive actors. Despite the different results, the institutional status quo hasn't changed.

Schmidt (2020, pp. 1180-1182) reminds that if the historical tracing of responses to critical junctures based on rational choice and constructivist approaches can provide explanations for policy change, that is only a 
partial analysis, insufficient to demonstrate if there was a reframing of institutional mechanisms and constitutional norms by the actors. If we agree that Covid-19 has resulted in policy-learning, we put into question if political ideology was a factor for policy shift and the change of Germany's position, as Ladi and Tsarouhas argue (2020, p. 1045). We tried to demonstrate that it was the particularity of the Covid-19 crisis that posed hegemonic actors in a non-alternative solution, or the possibility of the alternative solution being too dangerous for the survival of the EU, the single market, and thus for national economic growth strategies. Outputs were not the consequence of a voluntary ideological option, resulting from political competition at the EU level. While we acknowledge that from the Eurozone crisis a process of policy learning happened, boosted by the national politicization on the issue, with growing representativeness of Eurosceptic parties, and that such politicization is gradually reaching the EU institutions (Schmidt, 2020, p. 1186), this research argues that the Covid-19 decision-making itself was rather self-interest based than politicized based. Politicization means ideological contestation and competition based on majority dialects of power. If it happens in the EP, in the European Council bargaining, the goal is rather to reach unanimity to meet the consensus.

In Covid-19, path-dependencies and heightened awareness of self-interest dependent on common interest led to a step further in integration, nevertheless the consequent increased EU economic and financial powers can also be a time-bomb waiting to explode anytime a crisis generates junctural conditions to. Considering the new involved scope of EU fiscal competences, in the short term it may address citizens' demands and conceal the democratic issue, but not in the medium/long term. It is placed for the future the need to decide on the levels of taxation and their scope. The fiscal policy is at the heart of the governments of Western European democracies and is a typical element of partisan competition and public discontent. If future decisions are subject to the current constitutional and institutional mechanisms, it will replicate national economic conflicts, and the dialectics of power will remain the same. Van Loon (2021) case-study clarifies the influence of domestic preferences on EU taxation issues. Decisions that should be politically based will continue to be secured by territorial-based preferences. Thus, if the results of Covid-19 mitigate democratic legitimacy for some time, it may just be postponing and enhancing it in the next crisis. The prospects for a redistributive EU should not be at the expense of democracy, putting the competences that should be in the field of politics under a kind of technocratic federalism (Habermas, 2013, p. 5). In future moments of economic downturn, should the EU fail, what would be questioned is not the continuity of the EU executive, since the electorate cannot play a decisive role in choosing an alternative, but the EU itself as a political system. This is at the heart of Eurosceptic claims.

\section{Conflict of Interests}

The author declares no conflict of interests.

\section{References}

Abels, J. (2018). Power behind the curtain: The Eurogroup's role during the crisis and the value of informality in economic governance. European Politics and Society, 20(5), 519-534. https://doi.org/ 10.1080/23745118.2018.1542774

Arnold, M., \& Fleming, S. (2020, October 19). Eurozone budget deficits rise almost tenfold to counter pandemic. Financial Times. Retrieved from https:// www.ft.com/content/5579361f-5aac-4cd3-9e93190fffdcObaf

Beach, D., \& Pederson, R. B. (2016). Process-tracing methods. Foundations and guidelines. Ann Arbor, MI: The University of Michigan Press.

Bellamy, R., \& Weale, A. (2015). Political legitimacy and European monetary union: Contracts, constitutionalism and the normative logic of two-level games. Journal of European Public Policy, 22(2), 257-274.

Bennett, A. (2010). Process tracing and causal inference. In H. Brady \& D. Collier (Eds.), Rethinking social inquiry (pp. 207-220). Plymouth: Rowman and Littlefield.

Boffey, D. (2020, May 18). Merkel and Macron propose $€ 500 b n$ EU rescue fund. The Guardian. Retrieved from https://www.theguardian.com/world/2020/ may/18/merkel-and-macron-propose-500bn-eurescue-fund

Boffey, D., \& Rankin, J. (2020, July 21). EU leaders seal deal on spending and $€ 750$ bn Covid-19 recovery plans. The Guardian. Retrieved from https:// www.theguardian.com/world/2020/jul/20/macronseeks-endacrimony-eu-summit-enters-fourth-day

Braun, B. (2015). Preparedness, crisis management and policy change: The euro area at the critical juncture of 2008-2013. The British Journal of Politics and International Relations, 17, 419-441.

Capoccia, G. (2015). Critical junctures and institutional change. In J. Mahoney \& K. Thelen (Eds.), Advances in comparative historical analysis (pp. 147-179). Cambridge: Cambridge University Press.

Caporaso, J., \& Tarrow, S. (2008). Polanyi in Brussels: European institutions and the embedding of markets in society (RECON Online Working Paper Series, 1). Oslo: RECON.

Chang, M. (2009). Monetary integration in the European Union. London: Palgrave Macmillan.

Collier, D. (2011). Understanding process-tracing. Political Science, 44(4), 823-830.

Copelovitch, M., Frieden, J., \& Walter, S. (2016). The political economy of the Euro crisis. Comparative Political Studies, 49(7), 811-840.

Council Regulations (EC) No. 1466/97 of 7 July 1997 on the strengthening of the surveillance of budgetary 
positions and the coordination of economic policies. (1997a). Official Journal of the European Union, L 209/1.

Council Regulations (EC) No. 1467/97 of 7 July 1997 on speeding up and clarifying the implementation of the excessive deficit procedure. (1997b). Official Journal of the European Union, L 209/6.

Council Regulation (EC) No. 1467/97 of 8 November 2011 on speeding up and clarifying the implementation of the excessive deficit procedure. (2011). Official Journal of the European Union, L 306/33.

Darroch, G. (2020, May 3). Mark Rutte: The 'worldclass' pragmatist trying to take the drama out of the corona crisis. Dutch News. Retrieved from https://www.dutchnews.nl/news/2020/05/markrutte-the-world-class-pragmatist-trying-to-takethe-drama-out-of-the-corona-crisis

de Jongh, M., \& Theuns, T. (2017). Democratic legitimacy, desirability and deficit in EU governance. Journal of Contemporary European Research, 13(3), 1283-1300.

Delwit, P. (2015). Introduction à la science politique [Introduction to political science]. Brussels: Éditions de l'Université de Bruxelles.

European Central Bank. (2012). Compliance of outright monetary transactions with the prohibition on monetary financing. Frankfurt: European Central Bank.

European Central Bank. (2020a, June 4). Monetary policy decisions [Press Release]. Retrieved from https://www.ecb.europa.eu/press/pr/date/2020/ html/ecb.mp200604\%20 a307d3429c.en.html

European Central Bank. (2020b, March 18). ECB announces $€ 750$ billion pandemic emergency purchase programme [Press Release]. Retrieved from https://www.ecb.europa.eu/press/pr/date/2020/ html/ecb.pr200318_\%201 3949d6f266.en.html

Elliott, L., Inmam, P., \& Smith, H. (2013, June 5). IMF admits: We failed to realise the damage austerity would do to Greece. The Guardian. Retrieved from https://www.theguardian.com/business/2013/jun/ 05/imf-underestimated-damage-austerity-woulddo-to-greece

Eurogroup. (2020). Remarks by Mário Centeno, following the Eurogroup video conference of 9 April 2020. [Press Release]. Retrieved from https://www. consilium.europa.eu/pt/press/press-releases/2020/ 04/09/remarks-by-mario-centeno-following-theeurogroup-videoconference-of-9-april-2020

European Commission. (2011a). European renewal: State of the Union address (Speech No. 11/607). Brussels: European Commission.

European Commission. (2011b). Green paper on the feasibility of introducing stability bonds. Brussels: European Commission.

European Commission. (2012). A blueprint for a deep and genuine economic and monetary union launching a European debate. Brussels: European Commission.

European Commission. (2015). Completing Europe's eco- nomic and monetary union. Brussels: European Commission.

European Commission. (2020a). Communication: Europe's moment, repair and prepare for the next generation. Brussels: European Commission.

European Commission. (2020b). Communication to the Council, on the activation of the general escape clause of the Stability and Growth Pact (COM [2020]123 final). Brussels: European Commission.

European Commission. (2020c). Communication to the $E P$, the Council, and the ECB, on the 2021 draft budgetary plans: Overall assessment. Brussels: European Commission.

European Commission. (2020d). The impact of the Covid-19 pandemic on global and EU trade (17th April 2020). Brussels: European Commission.

European Commission. (2020e). The impact of the Covid-19 pandemic on global and EU trade (27th May 2020). Brussels: European Commission.

European Council. (2012). Towards a genuine economic and monetary union (Report EUCO120/12). Brussels: European Council.

European Council. (2020a, March 23). Statement of EU ministers of finance on the Stability and Growth Pact in light of the Covid-19 crisis [Press Release]. Retrieved from https://europa.eu/newsroom/ content/statement-eu-ministers-finance-stabilityand-growth-pact-light-covid-19-crisis_en

European Council. (2020b). Special meeting of the European Council. Conclusions (Report EUCO10/20). Brussels: European Council.

European Investment Bank. (2020). Coronavirus outbreak: EIB Group's response. European Investment Bank. Retrieved from https://www.eib.org/en/ about/initiatives/covid-19-response/index.htm

European Parliament Resolution (EP) No. 2011/2959 of 15 February 2012 on the feasibility of introducing stability bonds. (2012). Official Journal of the European Union, CE 249/2.

European Parliament Regulation (EP) No. 1175/2011 of 16 November 2011 amending Council Regulation (EC) No 1466/97 on the strengthening of the surveillance of budgetary positions and the surveillance and coordination of economic policies. (2011). Official Journal of the European Union, L 306/12.

European Parliament. (2020). Resolution of 17 April 2020 on EU coordinated action to combat the Covid-19 pandemic and its consequences (2020/2616). Brussels: European Parliament.

Fernandes, A. J. (2010). Introdução à ciência política [Introduction to political science]. Porto: Porto Editora.

Follesdal, A., \& Hix, S. (2006). Why there's a democratic deficit in the EU: A response to Majone and Moravcsik. Journal of Common Market Studies, 44(3), 533-562.

Gkasis, P. (2018). Greece and European monetary union: The road to the demise of Greek economy. In O. 
Parker \& D. Tsarouhas (Eds.), Crisis in the Eurozone periphery. The political economies of Greece, Spain, Ireland and Portugal (pp. 93-110). London: Palgrave Macmillan.

Gouveia, A. F. (2018). Completing the economic and monetary union: What economic and fiscal governance? In J. M Caetano \& M. R. de Sousa (Eds.), Challenges and opportunities for the Eurozone governance (pp. 121-144). New York, NY: Nova Science Publishers.

Habermas, J. (2013). Democracy, solidarity and the European crisis. Paper presented at the KU Leuven Euroforum, Leuven, Belgium.

Habermas, J. (2015). Democracy in Europe: Why the development of the EU into a transnational democracy is necessary and how it is possible. European Law Journal, 21(4), 546-557.

Heidebrecht, S. (2021). Financial crisis, emergency reforms, and the challenge for democratic governance at the centre of Eurozone. Unpublished manuscript.

Heinrich, M., \& Kutter, A. (2013). A critical juncture in EU integration? The eurozone crisis and its management 2010-2012. In F. E. Panizza \& G. Philip (Eds.), The politics of financial crisis. Comparative perspectives (pp. 120-139). London: Routledge.

Hillebrand, R. (2015). Germany and its Eurozone crisis policy. German Politics and Society, 33(1), 6-24.

Hix, S., \& Hoyland, B. (2011). The political system of the European Union. London: Palgrave Macmillan.

Inglehart, R. (1970). Public opinion and regional integration. International Organization, 24(4), 764-795.

Khan, M., \& Arnold, M. (2020, November 5). Brussels scales back expectations for EU's economic recovery. Financial Times. Retrieved from https:// www.ft.com/content/908fa7dc-9825-45b9-bba9$94 \mathrm{f07418fb} 13$

Kutter, A. (2020). Construction of the Eurozone crisis: Reand depoliticising European economic integration. Journal of European Integration, 42(5), 659-676.

Ladi, S., \& Tsarouhas, D. (2020). EU economic governance and Covid-19: Policy learning and windows of opportunity. Journal of European Integration, 42(8), 1041-1056.

Lang, G. (2004). Les politiques budgétaires et le pacte de stabilité [Budgetary politics and the Stability Pact]. In M. Dévoluy (Ed.), Les politiques économiques européennes [The European economic politics] (125-168). Paris: Éditions du Seuil.

Majone, G. (1996). La communauté Européenne: Un état régulateur [The European community: A regulatory state]. Paris: Montchrestien.

Merkel on eurobonds: 'Not in my lifetime.' (2012, June 27). Euro Active. Retrieved from https://www. euractiv.com/section/euro-finance/news/merkelon-eurobonds-not-in-my-lifetime

Moreira, V. (2017). "A vontade dos cidadãos da União": A democracia supranacional da União Europeia
["The will of the Union's citizens": The supranational democracy of the European Union]. Estudos do Século XX, 17, 45-80.

Moury, C. (2016). A democracia na Europa [Democracy in Europe]. Lisboa: Fundação Francisco Manuel dos Santos.

Parker, O., \& Tsarouhas, D. (2018). Causes and consequences of crisis in the Eurozone periphery. In 0. Parker \& D. Tsarouhas (Eds.), Crisis in the Eurozone periphery. The political economies of Greece, Spain, Ireland and Portugal (pp. 1-27). London: Palgrave Macmillan.

Pereira, L. B., \& Sousa, M. R. (2018). Towards a full banking union in Europe: Waiting for the next crisis? In J. M. Caetano \& M. R. Sousa (Eds.), Challenges and opportunities for the Eurozone governance (pp. 81-97). New York, NY: Nova Science Publishers.

Rankin, J. (2020, July 21). EU summit deal: What has been agreed and why was it so difficult? The Guardian. Retrieved from https://www.theguardian. com/world/2020/jul/21/eu-summit-dealwhat-

Reis, J. (2016). Quando a sombra domina a luz: A economia política do empobrecimento (Portugal pós-1993) [When shadow overshadows light: The economic politics of impoverishment (Portugal post-1993)]. In E. P. Ferreira (Ed.), União Europeia. Reforma ou declínio [European Union. Reform or decline] (pp. 46-48). Lisboa: Nova Vega.

Ruchet, J. (1998). La fiscalité des états de l'Union: Diversité ou divergences? [The fiscality of the Union states: Diversity or divergences]. In D. Schlacther (Ed.), Questions d'Europe. Le débat économique et politique [Questions on Europe. The economic and political debate] (pp. 168-177). Paris: Ellipses.

Sánchez-Cuenca, I. (2017). From a deficit of democracy to a technocratic order: The postcrisis debate on Europe. Annual Review of Political Science, 20, 351-369.

Scharpf, F. (1999). Governing in Europe, effective and democratic? Oxford: Oxford University Press.

Scharpf, F. (2010). The asymmetry of European integration, or why the EU cannot be a social market economy? Socio-Economic Review, 8(2), 211-250.

Schmidt, V. (2007). L'Union Européenne crée-t-elle ou détruit-elle la démocratie? [Does the European Union create or destroy democracy?]. Politique Étrangère, 3, 517-528.

Schmidt, V. (2013). Democracy and legitimacy in the European Union revisited: Input, output and throughput. Political Studies, 61, 2-22.

Schmidt, V. A. (2020). Theorizing institutional change and governance in European responses to the Covid19 pandemic. Journal of European Integration, 42(8), 1177-1193.

Schoeller, M. (2019). Leadership in the Eurozone. The role of Germany and EU institutions. Switzerland: Palgrave.

Snell, J. (2016). The trilemma of European economic and 
monetary integration, and its consequences. European Law Journal, 22(2), 157-179.

Sebastião, D. (2020). Parties in the EU political system. Growing determining actors? In R. Moldovan (Ed.), The European Union. Policies, perspectives and politics (pp. 131-152). New York, NY: Nova Science Publishers.

Shively, W. P. (2011). Power and choice. An introduction to political science. New York, NY: McGraw-Hill Companies.

Silva, A. M. (2017). A aventura da moeda única. Enredos e dilemas, processos e desafios: Ensaio de história e de política [Adventures of the single currency. Plots and dilemmas, processes and challenges: An essay of history and politics]. Coimbra: Imprensa da Universidade de Coimbra.

Stark, A. (2018). New institutionalism, critical junctures and post-crisis policy reform. Australian Journal of Political Science, 53(1), 24-39.

The Eurozone nine. (2020, March 26). Euro Intelligence.
Retrieved from https://www.eurointelligence.com The new channel of Eurozone instability, part 1 (2020, March 21). Euro Intelligence. Retrieved from https:// www.eurointelligence.com

Traynor, I., \& Wintour, P. (2012, May 24). Eurozone crisis: Germany and France clash over eurobonds at summit. The Guardian. Retrieved from https://www.theguardian.com/business/2012/ may/23/eurozone-crisis-france-germany-divide

Van Loon, A. (2021). European financial governance: FTT reform, controversies and governments' responsiveness. Politics and Governance, 9(2), 208-218.

Varoufakis, Y. (2017). Comportem-se como adultos [Behave like adults]. Oeiras: Marcador.

Verdun, A. (2015). A historical institutionalist explanation of the EU's responses to the Euro area financial crisis. Journal of European Public Policy, 22(2), 219-237.

Zalan, E. (2020, July 20). EU summit enters four day with recovery deadlocked. EU Observer. Retrieved from https://euobserver.com/economic/148985

\section{About the Author}

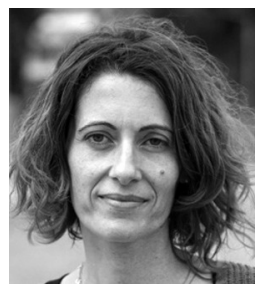

Dina Sebastião is an Assistant Professor at the University of Coimbra, Faculty of Arts and Humanities, and a research member at CEIS20. She holds a PhD in European Studies and has been researching EU policies and politics, mainly through the study of parties, the Europeanization, with a special focus on Portugal and Spain. Within these subjects, she has been participating in international conferences and published chapters and articles in several peer-reviewed journals. She was awarded the Jacques Delors 2017 Prize/Portuguese Ministry of Foreign Affairs for best academic study in EU issues. 